Article

\title{
Institutional Innovations and Their Challenges in the Green Climate Fund: Country Ownership, Civil Society Participation and Private Sector Engagement
}

\author{
Thomas Kalinowski (iD) \\ Graduate School of International Studies, Ewha Womans University, Seoul 03760, Korea; \\ kalinowski.thomas@gmail.com
}

Received: 5 September 2020; Accepted: 19 October 2020; Published: 23 October 2020

check for updates

\begin{abstract}
This article investigates the institutional innovations within the Green Climate Fund (GCF), a new international organization that finances climate mitigation and adaptation in developing countries. In particular, donor-recipient parity in decision making, civil society participation and private sector involvement are explored. The aim of this study is to lay the institutional groundwork for a larger study that will be analyzing the effect of these institutional innovations on the design and result of the fund's projects. An exploratory qualitative case study approach is used that includes the review of the secondary literature, official sources from the GCF, participant observation and semi-structured interviews. This article concludes that the GCF indeed implemented important institutional innovations that are unique for a major international organization. At the same time, this article reveals that these innovations have created some important challenges for the functioning of the fund. For example, donor-recipient parity, in combination with consensus orientation, initially led to gridlock. It is also difficult for the GCF to balance the goal of transparency and civil society participation with the need for secrecy of private contracts and a speedy process demanded by the private sector.
\end{abstract}

Keywords: climate finance; development cooperation; international organizations; Green Climate Fund; civil society participation; public-private partnership; multi-stakeholder governance

\section{Introduction}

Fighting climate change is not just a technical and technocratic problem but also-and maybe even primarily - an institutional and political problem. While natural scientists and engineers have developed technologies to create energy from renewable resources and build higher levees to protect coastal areas from rising sea levels, social scientists have so far struggled to understand why these technological fixes fail to materialize in a timely, effective and equitable way. The Global South is the most vulnerable to climate change and, at the same time, promising when it comes to effective climate mitigation. Reducing greenhouse gas emissions in developing countries offers considerably more bang for the buck compared with developed countries that have gradually been increasing their carbon efficiency since the 1970s. Renewable energy is cheaper to produce in the Global South and, because of its decentralized character, it can avoid costly investments in centralized power plants and the necessary power grid [1]. In this sense, renewable energy could be similar to the mobile internet, which helped developing countries to leapfrog expensive landline infrastructures [2]. At the same time, developing countries are more vulnerable to severe weather events related to climate change. Unfortunately, many countries and communities in the Global South lack money, technology and governance structures for successful climate adaptation and mitigation. In order to support developing 
countries in planning and financing climate adaptation and mitigation, the Green Climate Fund (GCF) was set up at the UNFCCC COP15 conference in Copenhagen in 2009 in a decision by 194 countries. It started its operation based in Songdo, South Korea, in 2010, and the first projects started in 2015. The goal of the GCF is to raise new and additional funds of USD 100 billion per year to finance climate change-related projects in developing countries. The intention is that the funds be evenly divided between climate adaptation and mitigation projects.

While the GCF is just one of many players in the field of climate adaptation finance, it is very important to study because it is a major new global player with an innovative institutional system reflecting experiences and debates in international organizations and development cooperation over the last decades. In particular, it reflects the critique of the World Bank for being undemocratic, secretive and dominated by donors, and for having little civil society participation. At the same time, the GCF reflects the neoliberal discourse on private sector participation that sees development cooperation not just as aid but also as a business opportunity. From this perspective, the public sector should use public funds to mobilize additional private capital and outsource not just the implementation but also the design and governance of projects to the private sector.

This paper argues that the GCF is indeed a major innovation when it comes to international organizations (IOs). It addresses many of the critiques of traditional IOs, such as donor orientation, lack of democracy and lack of civil society participation. Instead, the GCF is based on donor-recipient parity, consensus orientation, civil society participation and transparency. At the same time, this paper identifies four major problems. First, the fund has faced various gridlocks in board meetings due to its principle of consensus orientation. Second, while civil society participation is much stronger than that in other IOs, it is limited to a watchdog function, while the expertise of civil society groups is not systematically integrated in the design of projects. Third, private sector involvement is much more developed institutionally than in other IOs, but the GCF struggles to attract risk-averse private investments. It is also not clear how the promise to equally weight adaptation in the fund will be realized because, unlike the situation for climate mitigation, there is no persuasive business plan for adaptation projects. Fourth, the different institutional innovations are partly contradictory. As we demonstrate, recipient ownership focusing on quick disbursements frequently clashes with an active civil society that expects stakeholder participation and accountability. The focus on transparency also clashes with expanding the role of the private sector, which has a strong interest in protecting proprietary information and private contracts.

\section{Institutional Innovations in International Organizations}

Textbooks on the study of international organizations are dominated by the discourse between (neo-)"realists" that see IOs merely as a reflection of power struggles between nation states and (neo-)institutionalists, arguing that international institutions alter choices and behavior of states and are able to nurture long-term cooperation [3]. Both camps, however, agree on the dominant role of nation states and governments in IOs in which member states are either formally equals (like in the UN general assembly) or where there is a clear hierarchy (such as the dominance of donor countries in the World Bank). While these mainstream concepts might have reflected the roles of IOs until the 1990s, the emergence of a multipolar world, economic globalization and the rising importance of polycentric governance fundamentally changed the context in which IOs operate. The rise of important players from the Global South (such as China, India and many more) has weakened the leading role of the US and "the West" in IOs. Economic globalization meant that the economic interests of multinational corporations play an increasing role in IOs. Private businesses are now not just seen as contractors implementing projects decided by intergovernmental organizations, but as investors and partners [4]. Finally, actors below the national government levels such as transnational city networks [5] and civil society organizations (CSOs) now play an increasing role in the global political arena [6]. Amid the growing complexity of international relations, IOs are not simply agents anymore that "do what states want" but they deserved to be studied in their own right [7] (p. 2). Consequently, the success or failure 
of IOs not just depends on the willingness of states to cooperate but also on the way these IOs adapt to the changing reality and integrate different stakeholders.

Unfortunately, IOs are more known for their path dependency than their ability to change. The UN and the World Bank, for example, still largely reflect the state of international relations of the late 1940s when they were founded. Change comes in very incremental ways such as adding consultation with civil society and private sector or the long delayed and very timid quota reform in World Bank and the International Monetary Fund (IMF) to reflect the economic rise of East Asia [8] (pp. 86-87). Such gradual institutional innovations can be the result of adaptation and learning within organizations [9]. Unlike established institutions, new IOs such as the GCF can be more innovative in the attempt to reflect changed realities. Unlike in the World Bank, decisions would not be dominated by donors but decided based on the communication between donors and recipients as formally equal partners. CSOs and the private sector would be included in the process as additional stakeholders in the deliberation and decision-making process. While it is far from clear if these innovations will succeed-as this paper shows—-there are important lessons to be learned for current and future IOs from this kind of institutional experimentation.

In the GCF, instead a purely intergovernmental approach, the attempt was made to reflect new polycentric realities in the international relations by becoming more "polycentric" itself. The advantages of polycentric governance were described for the local level by Ostrom [10] and later expanded to include the international level as well [11,12]. "Polycentric systems are characterized by multiple governing authorities at differing scales rather than a monocentric unit" [13] (p. 552). Polycentric governance is seen as most useful where there are a lot of actors at different levels as is the case in the global climate crisis. Successful climate policies demand action not just from different levels of governments but the private sector and civil society as well. This focus on interaction and communication between diverse stakeholders has the potential to facilitate experimentation, build trust and improve cooperation over time [14]. While polycentricity highlights interaction between actors and organizations, it also has an influence on the organizations themselves as they adapt to a polycentric environment. The GCF operates within such a global "polycentric approach to climate governance" [12]. This polycentric environment facilitated certain institutional innovations as the GCF adopted a multi-stakeholder approach [15]. The GCF adapted this polycentric approach in the sense that it is primarily driven neither by powerful individual member states nor by a central hierarchy but through the interaction of different stakeholders at different levels from design, decision and implementation of policies and projects.

While the literature on the GCF is growing, there is so far still little research on the GCF as a working institution. Previous research tends to be focused on the process of setting up the GCF until 2015 [15-20] and the GCF in the larger context of climate justice [18] or development cooperation [19]. This is partly because the fund started to operate in 2010, but the first projects were only approved in 2015. The more recent studies that investigate the GCF at work have a rather narrow focus, for example, on the issue of country ownership [21] or the role of intermediaries [22]. This narrow focus limits their ability to understand how the different rules and institutions interact. Only by studying the interdependence of different institutional elements, such as donor-recipient parity, country ownership and private sector engagement, is it possible to evaluate the effect of these institutions on the work of the GCF. In fact, the GCF itself laments that it still lacks an independent evaluation of its work, as was highlighted numerous times at the 20th Board meeting of the GCF in Korea in July 2018 [23].

Recent challenges faced by the GCF have also not been properly reflected in the academic literature. The GCF has come under attack as US President Trump called the GCF "another scheme to redistribute wealth out of the United States ... to developing countries all on top of America's existing and massive foreign aid payments" [24]. While the US did not leave the GCF, it announced that it will not fulfill the pledges from the Obama administration and not provide additional funding [25]. In the GCF board meeting in July 2018, US board member Geoffrey Okamoto distanced himself from a polycentric operation of the fund and highlighted the importance of a donor-driven approach [26]. 
While (recipient) country ownership and civil society involvements are criticized by the Trump administration, private sector involvements are criticized by civil society groups. Scholars criticize greenwashing business as usual (BAU) projects and subsidies to private companies $[17,27]$ and more generally problematize the commodification and financialization of the environment as such [28].

Finally, the academic discourse on climate politics reflects a certain Northern bias. Mitigation-the main interest of the North-takes the center stage, while adaptation — the primary focus of the Global South - has taken a backseat. To date, most research on adaptation has focused on national or bilateral projects without specifically looking at multilateral institutions [29-33]. The literature on climate adaptation projects is less abundant, often focusing on issues of the legitimacy of project planning and not the projects themselves [34].

\section{Materials and Methods}

This article is part of the first stage of a larger research project on the GCF that we are currently planning. This first stage lays the foundation for future research by helping to identify problems and develop research questions and hypotheses (see the section on future research in the conclusions). For this purpose, we follow an explorative qualitative case study approach $[35,36]$ to investigate institutional innovations in the GCF. The strength of exploratory approaches is that they help to develop research questions and hypotheses for future research without the need to rely on elaborate theories that might offer a too narrow perspective on a new topic. While an approach that deducts hypotheses from an existing theory and then tests them empirically is appropriate where theories are established and data is reliable, the strength of an explorative approach is to inductively generate new theories. While not a comparative study of international institutions, this research puts the GCF into a broader context of international cooperation by comparing it with international organizations such as the UN, the World Bank and the GEF that also deal with climate mitigation and adaptation in developing countries. Such a most similar comparative study perspective is suitable for identifying and highlighting the distinct features of the GCF as an institution.

The described exploratory approach seems appropriate as the GCF is a relatively new institution that is still evolving and on which there is still limited existing research. In addition to the limited secondary literature, this paper relies on the GCF's website and its data portal (https://www.greenclimate. fund) as the main source of data. In particular, the proceedings and decisions made at the board meeting as well as the live streams and videos of board meetings provided on the website were used. The website provides a database where all relevant documents and data for the GCF projects can be accessed. In addition, a questionnaire with open-ended questions was send to GCF staff and a limited number of semi-structured interviews with civil society representatives and experts were conducted. The purpose of the questionnaire and the interviews was not primarily to generate data for the analysis but to explore problems, hypotheses, opinions and discourses on the work of the GCF. Finally, the method of participant observation $[37,38]$ was also employed, as the main author participated in GCF board meetings as a passive NGO observer. Participant observation is an established qualitative research method that allows to gain a deeper understanding of the context in which institutional mechanisms are at work. Such observations are particularly useful for explorative research as questions and problems that would remain undiscovered in theory-led deductive approaches or research purely based on official data and interviews.

\section{Institutional Innovations and Their Problems in the GCF}

\subsection{The GCF as an Innovative International Institution}

The GCF is a public international organization that differs substantially from other international organizations, such as the UN, IMF and World Bank, in at least four major aspects (see Table 1). First, the GCF maintains a parity of donor and recipient countries in the governing council, differing from the donor-dominated shareholder model of the World Bank (and the IMF). The GCF is governed by 
a 24-member board that consists of 12 members from developed (donor) countries and 12 developing (recipient) countries [39]. Country ownership is a guiding principle in order to ensure that projects are in line with national climate plans of recipient countries ("no objection procedure"). When it comes to the decisions on projects, we can even attest that they are recipient-driven (see Section 4.2). Second, the GCF embraces a multi-stakeholder approach that includes the regional level and civil society participation (see Section 4.3). While it took the Word Bank and other international institutions decades to acknowledge the importance of civil society participation, the GCF has built in civil society involvement from the beginning. Currently (October 2020), 296 CSOs are registered as observers at the GCF, and two representatives of the CSOs (one from a developed and one from a developing country) can participate in GCF meetings, although they are not eligible to vote [40]. Board meetings are also streamed on the internet to increase transparency of the fund's operation. Third, the GCF takes cooperation with the private sector to a new level (see Section 4.4). While country ownership is a guiding principle, the GCF simultaneously emphasizes an aim to "maximize fund-wide engagement with the private sector" [41] (p. 62). The private role goes far beyond raising capital in financial markets and includes a Private Sector Facility in which the private sector takes the lead. Currently, about $40 \%$ of the GCF project funding is classified as "private sector". The Private Sector Advisory Group (PSAG) ensures that private sector interests are included in the planning stages of projects. The private sector can be involved at any stage, from the planning of financing to the implementation of projects, although the degree varies substantially from project to project. The GCF is thus part of a general trend of at least partly privatizing development cooperation, where projects are not just seen in terms of their contribution to the public good but also from the perspective of private investors and with respect to their profitability. Fourth, the GCF embraces not just multi-stakeholder governance but also a polycentric implementation of projects. GCF projects are not implemented by the GCF itself but by 71 accredited institutions (as of October 2020), which include public development agencies, regional development banks and NGOs, as well as private companies, banks and investment funds [42]. At the same time, the GCF funds a broad variety of projects, from big projects to small and micro-projects, and is thus also polycentric in the spirit of Elinor Ostrom [10]. The GCF also offers a simplified approval procedure for small and micro-projects and distinguishes itself from the traditional orientation of development cooperation towards big donor-driven projects.

Table 1. International organizations from a comparative perspective.

\begin{tabular}{|c|c|c|c|c|}
\hline & UN & World Bank/IMF & GEF & GCF \\
\hline IO type & Intergovern-mental & Intergovern-mental & Intergovern-mental & Polycentric-intergovern-mental \\
\hline Decision making & Majority & Majority & Consensus & Consensus-oriented and voting \\
\hline Voting principle & $\begin{array}{l}\text { One country } \\
\text { one vote }\end{array}$ & $\begin{array}{l}\text { Shareholder } \\
\text { principle (one } \\
\text { dollar one vote) }\end{array}$ & $\begin{array}{l}16 \text { developing, } \\
14 \text { developed, } \\
2 \text { transition }\end{array}$ & Donor-Recipient Parity \\
\hline Decisions are & Member-driven & Donor-driven & $\begin{array}{l}\text { Recipient-driven } \\
\text { (project proposal) }\end{array}$ & $\begin{array}{l}\text { Recipient-driven } \\
\text { (project proposal) }\end{array}$ \\
\hline Veto & In security council & $\begin{array}{c}15 \% \text { (for } \\
\text { major decisions) }\end{array}$ & Consensus & $1 / 3$ of vote \\
\hline $\begin{array}{l}\text { Civil society } \\
\text { participation }\end{array}$ & Weak & Weak & Moderate & Strong \\
\hline $\begin{array}{l}\text { Private sector } \\
\text { involvement }\end{array}$ & Weak & Weak & Weak & Strong \\
\hline
\end{tabular}

The international organization that is most related in purpose and institutional framework is the Global Environmental Facility (GEF), which is part of the World Bank but functionally independent with its own decision-making process. In the GEF, developing countries represent half of the council (16 out of 32), while developed countries (14) and transition economies (2) fill the other half. The GEF makes decisions strictly based on consensus, and even one council member can block projects. When it comes to the participation of NGOs, the GEF is stronger than in other IOs but weaker than in the 
GCF as CSOs participation largely outsourced to consultations before the council meetings that not all council members attend [15]. The more state-centered orientation in the GEF is even more pronounced when it comes to private sector involvement.

In sum, the GCF embodies a compromise between recipient countries that want more country ownership, the profit-seeking private sector seeking business opportunities and the civil society sector pressing for a multi-stakeholder approach. The GCF is arguably the first major international organization that was set up by governments but, at the same time, embraces transnational polycentric governance and, in particular, an integral role of the private sector in all aspects of the fund's operation from the beginning. The tension between country ownership, the strong role of the private sector and civil society participation are an interesting and important area of research that is relevant far beyond the GCF and climate finance.

\subsection{The Challenges of Donor-Recipient Parity and Consensus Orientation}

Various challenges have arisen from institutional innovations within the GCF. Consensus orientation is a laudable objective, but the necessity to reach a consensus to make decisions has led to various gridlocks on the GCF board. There are numerous conflict lines that are not just between donors and recipients but also more generally about the purpose of the fund. Those in favor of funding proposals will always try to display them as mere technocratic projects, while, in fact, most decisions are political and set precedence for future decisions. A common reason for objections is "Doubts about sufficient transparency and disclosure of potential negative environmental and social impacts for high-risk sub-projects and their management and implementation in compliance with GCF requirements" [43]. As a young organization, setting precedence is a major concern of board members, which makes decisions more difficult. Any project decision will influence future decisions and standards concerning transparency and accountability for future projects without the exact consequences being known to the decision makers. The need for consensus can also aggravate conflicts, as geopolitical conflicts can spill over into GCF decisions. For example, the trade conflict between the US and China played a role in the US objection to the Chinese project "Catalyzing Climate Finance (Shandong Green Development Fund" (GCF FP.82). The US feared that GCF funding would be used for research and development for commercial products and thus increase Chinese competitiveness [43]. Potentially, the need for a consensus could undermine operations by leading to a tit for tat, where decisions are made based on past voting behaviors of others and not based on the issue at hand.

The low point of GCF governance and the most serious gridlock happened in the 20th board meeting in July 2018 when it took two of the four meeting days to agree on the agenda; in the remaining time, not a single project was approved, and executive director Howard Bamsey resigned [26]. In the meeting, it became clear that the GCF would not be governable with consensus orientation alone. Governance reform was discussed from the beginning, but while developed countries and vulnerable developing countries were in favor of a governance reform that would speed up project approval, less vulnerable developing countries, such as Saudi Arabia, Egypt and Iran, were opposed [44]. Only the collapse of the 20th board meeting made it possible to ultimately achieve a consensus on establishing a voting system in the GCF. Finally, at the 23rd board meeting in July 2019, a procedure of decision making in the absence of a consensus was agreed upon. The board decided that if all attempts to reach a consensus are exhausted, then decisions can be made with a qualified majority of 2/3 (GCF B.23/09). The procedure was used for the first time on the abovementioned Chinese project FP82 at the 24th board meeting in November 2019 (GCF B.24/09). Japan and the United States-two of the largest donors-voiced objections, but in the resulting vote, the project was approved, and these countries were overruled by a qualified majority of 19 members, with two against and one abstention. It remains to be seen how the US will react to this defeat, and it is not unlikely that, in the case of the reelection of President Trump, the US will leave not just the Paris Agreement but also the GCF.

The establishment of a voting process is an important step for the GCF to improve its ability to make faster decisions. The established voting procedure, however, will not overcome the more fundamental 
cleavages in the board and, in particular, the fundamentally different interests of donors and recipients. Recipients are interested in a growing fund with a fast disbursement of money to projects that offer the broadest benefit to their constituency. Donors are interested in the effectiveness and transparency of projects that are narrowly focused on climate goals. These conflicts do not necessarily need to lead to gridlock. On the contrary, as both sides have good arguments, projects need to address concerns from both sides, leading to better project designs and more transparency and accountability. An important advantage of the GCF is that, unlike in other international organizations, recipient countries have a strong presence in the board meetings. In the World Bank and IMF, similar to a commercial bank, the donors decide on the conditions of grants and credits. Recipients only have the choice to take it or leave it. In the GCF, recipients do not just have parity in the board: they also have superior knowledge of the projects that they propose (often in consortiums with aid agencies). Consequently, recipients tend to have the upper hand in project approvals, while donors can merely block proposals that they consider inadequate. When it comes to replenishment, however, donors naturally have the upper hand. In this sense, US board member Okamoto was right when he stated in 2018 that replenishment is a donor-driven process [45] because additional commitments to funding need to be decided by the governments of donor countries and not by the GCF. In the replenishment, donor countries can demand changes to the rules of operation and insist on strict performance evaluations. It remains to be seen if the ongoing first replenishment in 2020 will succeed in raising enough funds, particularly since it is unlikely that the US will ever release the originally pledged amount, let alone make additional pledges. It also remains to be seen how the performance of ongoing projects will influence replenishments. As more and more projects will be evaluated over time in this still-young organization, donors are expected to gain more information and thus leverage over recipient countries.

While recipient countries have an unprecedented influence in the GCF board compared with other international organizations, and recipients have a stronger position in the project approval process, these institutional innovations are not sufficient to empower the Global South in a broader sense. First, as mentioned above, recipient countries are divided on several issues, from governance reform to funding priorities. Additionally, institutional innovations have given developing countries a voice and decision-making power, but this has not led to necessarily stronger ownership by the Global South in the projects themselves. Most GCF projects are dominated by international institutions and not national entities in recipient countries, not to mention local ones that are closest to the communities. In fact, $86 \%$ of all projects are run by these so-called international access entities, and only $14 \%$ are managed by local access entities. All local entities together implement fewer projects than the largest international entity, the European Bank for Reconstruction and Development (EBRD), which alone manages $18 \%$ of all approved GCF funding [43]. Institutionally, small and subnational organizations are explicitly included as partners in a polycentric framework but in practice, stringent requirements and extensive reporting demanded by the GCF and donor countries make it difficult for those small players to become involved. Readiness activities by the GCF have helped to improve the ability of "national designated agencies" (NDAs) within the government of recipients but the inclusion of subnational stakeholders remains a major challenge [21].

\subsection{Civil Society: Participation without Representation}

The degree of civil society engagement is an important part of the GCF's work. In most intergovernmental organizations, civil society participation is virtually non-existent (e.g., NATO), very limited (IMF, World Bank, WTO) or outsourced to separate civil society summits (G20). The GEF is a partial exception, although, even here, CSO participation was only later added by a GEF council decision [46]. The observer status in the GEF is only granted by the CEO "in consultation with the Council" [47], implying that the CSOs depend on the goodwill of the CEO and all council members. In all of these established intergovernmental organizations, civil society participation was included later. Often, this reluctantly happened as a reaction to public protests against summit meetings, starting with the IMF/World Bank annual meeting in Berlin in 1988 and the protest against the WTO 
in Seattle in 1999. In the case of the GCF, civil society participation was an integral part from the beginning. CSO participants are divided into active and passive observers. Two active observers (one from a developed country, one from a developing country) and two alternate observers (same) participate in the board meetings. A large number of passive observers follow the board meeting in a separate room while being in touch with "their" active observers through electronic communication. In addition, all board meetings are streamed live on the internet, where observers and the interested public can follow them. To what degree active observers have the right to actively participate in board meetings is still controversial and evolving. While it is obvious that observers do not have the right to vote, it is unclear what exact rights they have and if they are, for example, entitled to speak. The rules of procedure of the board (GCF B.01-13/12: VI) state that "Active observers may, upon invitation of the Co-Chairs, participate in the proceedings of the Board." The formulation "participate in the proceedings of the Board" implies that the GCF members want the civil society participants to be more active than simply being able to observe the proceedings. However, the term "upon invitation" could be understood to mean that active observers are only allowed to speak upon the invitation of the co-chairs. Over time, however, it has become customary, although not undisputed, that CSO representatives are able to contribute to all discussed items. It also remains unclear what the CSO rights are outside the board meetings and if they are, for example, able to demand documents from the secretariat. The ability to work with the secretariat between board meetings would be crucial not just to effectively participate in the proceedings but also to be able to hold the secretariat accountable for their work. So far, however, the ability of observers to participate actively depends on the goodwill of the co-chairs or the support from at least one board member with voting rights that is demanding the observers' input.

In the GCF board meetings, the role of civil society has become very important in the discussions of the board and its role in overseeing the work of the secretariat. Through their networks in recipient countries, civil society representatives are often very well informed about the downsides of projects or the reputation of entities seeking accreditation. On the one hand, many board members appreciate this input, as it allows them to more effectively monitor the work of the secretariat and get a bigger picture of pending decisions. There have been several cases in which board members with voting rights used the input of civil society representatives to demand further clarifications from the secretariat. There are, however, also cases in which board members voiced discontent with the role of civil society and demanded to go ahead with a decision without seeking the clarifications demanded by the civil society. Ultimately, civil society groups depend on building alliances with voting board members, and it would be particularly helpful to coordinate the work of civil society observers and voting board members between the board meetings. While civil society groups from donor and recipient countries are remarkably unified in their position, they sometimes side with board members from recipient countries, and sometimes they support positions from the donor's side. In sum, civil society actors support recipients when it comes to replenishment and a broad mandate for the fund. At the same time, they are in favor of more transparency and accountability, which is a position favored by donors.

\subsection{The Difficulties of Private Sector Involvement}

Private sector involvement has been an important priority for the GCF. Amid the lack of commitment from governments, large parts of the USD 100 billion annual spending goal would have to come from the private sector. Thus, the systematic inclusion of the private sector is an institutional innovation where the GCF has gone much further than any other comparable intergovernmental organization. The private sector is not merely seen as an executor of projects but is supposed to be included directly in the design and application of projects (see above). Similar to civil society representatives, the private sector also sends two active observers to the board. The GCF takes cooperation with the private sector to a new level. While country ownership is a guiding principle, the GCF simultaneously emphasizes an aim to "maximize fund-wide engagement with the private sector" [41] (p. 62). The Private Sector Advisory Group (PSAG) ensures that private sector interests are 
included in the planning stages of projects. The private sector is involved at any stage, from planning and financing to the implementation of projects, although the degree varies substantially from project to project. The GCF is thus a part of a general trend of at least partly privatizing development cooperation, where projects are not just seen in terms of their contribution to the public good but also from the perspective of private investors and with respect to their profitability.

The private role goes far beyond raising capital in financial markets and includes a Private Sector Facility in which the private sector takes the lead. Currently, there are 26 private sector projects, with a total volume of USD 8.6 billion, which is about $36 \%$ of all GCF projects. Of the 8.6 billion, about 1.9 billion comes from the GCF, with USD 6.7 billion of co-financing. While it seems that private sector involvement is substantial, a closer look at the projects reveals that only parts of the co-financing are actually coming from private sources. In many private sector projects, large parts of the co-financing come from other public entities, such as the EBRD. In fact, in some of the "private sector projects", 100\% of financing comes from public entities (e.g., FP.25, FP.39). The reason that these projects are classified as private sector is, for example, because they have the goal of "scaling up private sector climate finance" (FP.25) in the future. In addition, as the plan is often to raise private funding through equity participation, a project approval does not automatically mean that the funding is already available because the GCF and the accredited entities first need to find those additional private investors. As equity investments carry a particularly high risk, this is often a bigger problem than expected. Consequently, it seems that funding from private sources is much lower than the aggregated numbers of the GCF imply.

So far, the promised mobilization of private funds has fallen far short of the ambitious goals because businesses are concerned about scrutiny during the accreditation process and remain averse to taking risks in a challenging business sector. In particular, climate adaptation projects are shunned by the private sector because they inherently lack a profitable business model. While solar or wind energy parks can no doubt be run as a profit-generating business, such a perspective is far less obvious for levees or for adapting existing businesses or infrastructure to withstand severe weather events. The strategy of the GCF goes far beyond mere climate projects, as it highlights its aim to use public resources to develop new businesses. In fact, it is an explicit goal of the GCF to help companies develop profit-generating projects. The goal of private sector involvement is not limited to climate mitigation and adaptation, but it openly supports private sector development. In this sense, the GCF is not just an international environmental organization but also active in development cooperation.

The strong emphasis on including the private sector could be promising to the support of sustainability and development, but it also has drawbacks. First, scarce public resources are used to facilitate private investments by reducing risk for the private sector. Thus, less resources are available for public sector projects. While, in theory, the mobilization of private funds might sound like a sound investment of taxpayers' money, in reality, it seems difficult to achieve. Even if it worked, it remains controversial why the public sector should take the risks while private companies reap the profits (that, in theory, are supposed to be the reward for risk-taking). It is questionable whether these projects would not be better carried out by the public sector, with the private sector limited to implementation. Mixed experience with public-private partnership (PPP) projects in developed countries $[48,49]$ also calls for careful scrutiny of such GCF projects, as the public sector is already weaker in the developing world. PPP projects funded by international organizations might also further undermine public sector capacity in these countries and thus the country ownership goal of the GCF. In addition, private sector involvement has a certain tension with the GCF goal of transparency and accountability that is taken very seriously by donors and civil society. By definition, the private sector (lat. privatim = not public, confidential) is not transparent and based on private (i.e., confidential) contracts. A partnership between public and private sectors will thus always include some kind of trade-off with transparency. In the PPP logic, demands for transparency and accountability will always be seen as a discouragement and obstacle for private sector involvement. 
While it is too early for a full assessment of private sector involvement, some tendencies are expected and can already be observed to some degree. First, given the above-described risks and contradictions, the public sector is hesitant to be involved. Second, the role of the private sector in the GCF might be one reason that there is a certain bias for mitigation projects because there is so far no plausible plan for how to design profitable adaptation projects. Finally, a major issue for the private sector is the accreditation process to become an entity entitled to apply for and/or implement projects. Naturally, the accreditation process is comprehensive because the GCF needs to ensure that only credible entities can become partners. As taxpayer's money is spent, such scrutiny is necessary and will also reduce the risk of scandals that may undermine the legitimacy (and replenishment) of the GCF in the future. The problem is that small companies and NGOs will find it difficult to fulfill all requirements of the accreditation process. In addition, businesses want to avoid closer scrutiny of their business models by an organization that, unlike private banks, prides itself on its transparency.

\section{Conclusions}

\subsection{Institutional Innovations and Their Problems}

The GCF is a new international organization with many institutional innovations. The GCF reflects a world in which the Global South has a stronger voice. The institution has learned from critiques such as undemocratic decision making, dominance of donors and lack of country ownership associated with the IMF and World Bank. The GCF is more democratic, and there is a parity between donors and recipient countries in decision making. Country ownership is highlighted, while voices from civil societies are included systematically in the decision-making process and the monitoring of the secretariat. The GCF is more transparent than other institutions, with board meetings streamed live and documents available on the website. At the same time, the GCF has embraced the broad involvement of the private sector and has gone much further in this respect than other intergovernmental organizations. The GCF does not just systematically include the private sector in project design and implementation: it also sees the private sector as a partner to raise capital and generate profits. The GCF is thus much more than a climate agency but is deeply involved in developing economies in the Global South through public-private partnerships. As a result of the institutional innovations, there are substantial tensions between partly conflicting goals. Donor-recipient parity makes replenishment more difficult, while consensus orientation undermines ambitious spending goals. Transparency and civil society participation discourage private sector involvement, while the latter undermines the objective to channel half of the fund's spending to climate adaptation projects. Given the short history of the GCF, however, it is necessary to study these contradictions and the effect of these institutional innovations in more detail.

\subsection{Future Research}

This first stage of research presented here had the goal of exploring the GCF as an institution and identifying problems and research questions for a larger future research project. In this future research project, currently under preparation, we want to study more systematically how the institutional innovations of the GCF influence the design and performance of projects. Such a project would compare the current (August 2020) 141 climate projects managed by the GCF. We would like to answer the following questions:

1. How does the polycentric structure of the fund work in practice, and what kind of challenges does the GCF meet?

2. How does the tension between country ownership and private sector participation play out in the operation of the fund? How are private sector engagement and civil society consultation integrated into the operation of the GCF? Where do business and civil society interests work together, and in which cases do they clash which each other? 
3. How do different ways of financing (grants/loans/public/private), scales (micro/small/medium/large) as well as implementation agencies (multinational/national/local/public/private/CSO) affect the planning and the outcome of the projects? Which of the above factors is most successful when it comes to achieving the goals of the GCF? Most importantly, which projects are most successful in reducing emissions (mitigation) and protecting the most vulnerable from the effects of climate change (adaptation)?

4. How does the GCF ensure that it mobilizes additional private funds that do not crowd out private investments? How does the GCF ensure that GCF funds are not misused to subsidize private companies? How does the GCF support climate adaptation mainstreaming while ensuring that climate adaptation is not used for greenwashing business as usual (BAU) projects? What roles do civil society organizations play in ensuring transparency and accountability of private sector projects?

Funding: This research received funding from Ewha Womans University grants no. 1-2019-1542-001-2 and 1-2020-0815-001-1.

Conflicts of Interest: The authors declare no conflict of interest.

\section{References}

1. Zhang, F. Can solar panels leapfrog power grids? The World Bank experience 1992-2009. Renew. Sustain. Energy Rev. 2014, 38, 811-820. [CrossRef]

2. Goldemberg, J. Technological Leapfrogging in the Developing World. Georget. J. Int. Aff. 2011, 12, 135-141.

3. Rittberger, V.; Zangl, B.; Kruck, A. International Organization, 2nd ed.; Palgrave Macmillan: Basingstoke, UK; New York, NY, USA, 2012.

4. Lund-Thomsen, P.; Wendelboe Hansen, M.; Lindgreen, A. Business and Development Studies: Issues and Perspectives; Routledge Taylor \& Francis Group: London, UK; New York, NY, USA, 2020; p. xxiii.

5. Niederhafner, S. Comparing functions of transnational city networks in Europe and Asia. Asia Eur. J. 2013, 11, 377-396. [CrossRef]

6. Chandler, D. Constructing Global Civil Society: Morality and Power in International Relations; Palgrave Macmillan: Basingstoke, UK; New York, NY, USA, 2004.

7. Barnett, M.N.; Finnemore, M. Rules for the World: International Organizations in Global Politics; Cornell University Press: Ithaca, NY, USA, 2004.

8. Kalinowski, T. Why International Cooperation is Failing: How the Clash of Capitalisms Undermines the Regulation of Finance, 1st ed.; Oxford University Press: Oxford, UK, 2019. [CrossRef]

9. Haas, E.B. When Knowledge is Power: Three Models of Change in International Organizations; University of California Press: Berkeley, CA, USA, 1990.

10. Ostrom, E. A Polycentric Approach for Coping with Climate Change; World Bank Policy Research Working Paper 5095; The World Bank: Washington, DC, USA, 2009.

11. Jordan, A.; Huitema, D.; van Asselt, H.; Forster, J. Governing Climate Change: Polycentricity in Action? Cambridge University Press: Cambridge, UK, 2018.

12. Dorsch, M.J.; Flachsland, C. A Polycentric Approach to Global Climate Governance. Glob. Environ. Politics 2017, 17, 45-64. [CrossRef]

13. Ostrom, E. Polycentric systems for coping with collective action and global environmental change. Glob. Environ. Chang. 2010, 20, 550-557. [CrossRef]

14. Cole, D.H. Advantages of a polycentric approach to climate change policy. Nat. Clim. Chang. 2015, 5, 114 . [CrossRef]

15. Abbott, K.W.; Gartner, D. The Green Climate Fund and the Future of Environmental Governance; Earth System Governance Working Paper, No. 16; Earth Systems Governance Project: Amsterdam, The Netherlands, 2011.

16. Horstmann, B.; Hein, J. Aligning Climate Change Mitigation and Sustainable Development Under the UNFCCC: A Critical Assessment of the Clean Development Mechanism, the Green Climate Fund and REDD; Deutsches Institut für Entwicklungspolitik: Bonn, Germany, 2017.

17. Bracking, S. The Anti-Politics of Climate Finance: The Creation and Performativity of the Green Climate Fund. Antipode 2015, 47, 281-302. [CrossRef] 
18. Vanderheiden, S. Justice and climate finance: Differentiating responsibility in the Green Climate Fund. Int. Spect. 2015, 50, 31-45. [CrossRef]

19. van Kerkhoff, L.; Ahmad, I.H.; Pittock, J.; Steffen, W. Designing the Green Climate Fund: How to Spend $\$ 100$ Billion Sensibly. Environ. Sci. Policy Sustain. Dev. 2011, 53, 18-31. [CrossRef]

20. Markandya, A.; Antimiani, A.; Costantini, V.; Martini, C.; Palma, A.; Tommasino, M.C. Analyzing Trade-offs in International Climate Policy Options: The Case of the Green Climate Fund. World Dev. 2015, 74, 93-107. [CrossRef]

21. Zamarioli, L.H.; Pauw, P.; Grüning, C. Country Ownership as the Means for Paradigm Shift: The Case of the Green Climate Fund. Sustainability 2020, 12, 5714. [CrossRef]

22. Chaudhury, A. Role of Intermediaries in Shaping Climate Finance in Developing Countries-Lessons from the Green Climate Fund. Sustainability 2020, 12, 5507. [CrossRef]

23. Green Climate Fund (GCF). 20th Board Meeting Video Recordings. Available online: https://gcf.meta-fusion. com/b20/channels/gcf-live-b20 (accessed on 19 October 2020).

24. Trump, D. Statement by President Trump on the Paris Climate Accord, 1 June 2017. Available online: https: //www.whitehouse.gov/briefings-statements/statement-president-trump-paris-climate-accord/ (accessed on 19 October 2020).

25. Bowman, M.; Minas, S. Resilience through interlinkage: The green climate fund and climate finance governance. Clim. Policy 2019, 19, 342-353. [CrossRef]

26. Darby, M. UN Climate Fund Chief Resigns for Personal Reasons while Board Meeting Collapses. Available online: http://www.climatechangenews.com/2018/07/04/un-climate-fund-chief-resigns-personalreasons-board-meeting-collapses/ (accessed on 23 October 2020).

27. Pauw, W. Not a panacea: Private-sector engagement in adaptation and adaptation finance in developing countries. Clim. Policy 2015, 15, 583-603. [CrossRef]

28. Sullivan, S. Banking Nature? The Spectacular Financialisation of Environmental Conservation. Antipode 2013, 45, 198-217. [CrossRef]

29. Runhaar, H.; Wilk, B.; Persson, Å.; Uittenbroek, C.; Wamsler, C. Mainstreaming climate adaptation: Taking stock about "what works" from empirical research worldwide. Reg. Environ. Chang. 2017, 18, 1201-1210. [CrossRef]

30. Kartez, J.D.; Merrill, S.B. Climate Adaptation Finance Mechanisms: New Frontiers For Familiar Tools. J. Ocean Coast. Econ. 2016, 3, 4. [CrossRef]

31. Ayers, J.M.; Huq, S. Supporting adaptation to climate change: What role for official development assistance? Dev. Policy Rev. 2009, 27, 675-692. [CrossRef]

32. Druce, L.; Moslener, U.; Gruening, C.; Pauw, W.; Connell, R. Demystifying Adaptation Finance for the Private Sector; The United Nations Environment Programme: Nairobi, Kenya, 2016.

33. Pauw, W.P. From Public to Private Climate Change Adaptation Finance: Adapting Finance or Financing Adaptation? Ph.D. Thesis, Utrecht University, Utrecht, The Netherlands, 2017.

34. Lebel, L.; Salamanca, A.; Kallayanamitra, C. The governance of adaptation financing: Pursuing legitimacy at multiple levels. Int. J. Glob. Warm. 2017, 11, 226-245. [CrossRef]

35. Sjoberg, G.; Williams, N.; Vaughan, T.; Sjoberg, A. The Case Study Approach in Social Research; UNC Press Books: Chapel Hill, NC, USA, 1991; pp. 27-79.

36. Harrison, H.; Birks, M.; Franklin, R.; Mills, J. Case study research: Foundations and methodological orientations. FQS Forum Qual. Sozialforsch. 2017, 18, 19.

37. Clark, A.; Holland, C.; Katz, J.; Peace, S. Learning to see: Lessons from a participatory observation research project in public spaces. Int. J. Soc. Res. Methodol. 2009, 12, 345-360. [CrossRef]

38. Iacono, J.; Brown, A.; Holtham, C. Research Methods-A Case Example of Participant Observation. Electron. J. Bus. Res. Methods 2009, 7.

39. Green Climate Fund (GCF). GCF Board Composition. Available online: https://www.greenclimate.fund/ boardroom/board-members (accessed on 19 October 2020).

40. Green Climate Fund (GCF). GCF Observer Directory. Available online: https://www.greenclimate.fund/howwe-work/tools/observer-directory/civil-society (accessed on 19 October 2020).

41. Green Climate Fund (GCF). Decisions of the Board-Seventh Meeting of the Board 18-21 May 2014. Available online: https://www.greenclimate.fund/document/gcf-b07-11 (accessed on 23 October 2020). 
42. Green Climate Fund (GCF). Accredited Entity Directory. Available online: https://www.greenclimate.fund/ how-we-work/tools/entity-directory (accessed on 19 October 2020).

43. Schalatek, L. "Back to the Future” for GCF After Recent Bahrain Board Meeting. Available online: https: //us.boell.org/2018/11/08/back-future-gcf-after-recent-bahrain-board-meeting (accessed on 23 October 2020).

44. Darby, M. UN Fund Removes Veto Power over Climate Projects. Available online: https:// www.climatechangenews.com/2019/07/09/un-fund-removes-veto-power-climate-projects/ (accessed on 23 October 2020).

45. Darby, M. 8 Takeaways from The Green Climate Fund Meltdown. Available online: https: //www.climatechangenews.com/2018/07/06/8-takeaways-green-climate-fund-meltdown/ (accessed on 23 October 2020).

46. de Chazournes, L.B. The Global Environment Facility as a Pioneering Institution: Lessons Learned and Looking Ahead; GEF Working Paper 19; Global Environment Facility: Washington, DC, USA, 2003.

47. Global Environment Facility. Rules of Procedure for the GEF Council. Available online: https://www.thegef. org/sites/default/files/publications/11488_English_2.pdf (accessed on 23 October 2020).

48. Ruügemer, W. Heuschrecken im Oöffentlichen Raum: Public Private Partnership-Anatomie Eines Globalen Finanzinstruments; Transcript: Bielefeld, Germany, 2008; 169p. (In German)

49. Whiteside, H. About Canada: Public-Private Partnerships; Ferwood Publishing: Halifax, NS, Canada, 2016.

Publisher's Note: MDPI stays neutral with regard to jurisdictional claims in published maps and institutional affiliations.

(C) 2020 by the author. Licensee MDPI, Basel, Switzerland. This article is an open access article distributed under the terms and conditions of the Creative Commons Attribution (CC BY) license (http://creativecommons.org/licenses/by/4.0/). 